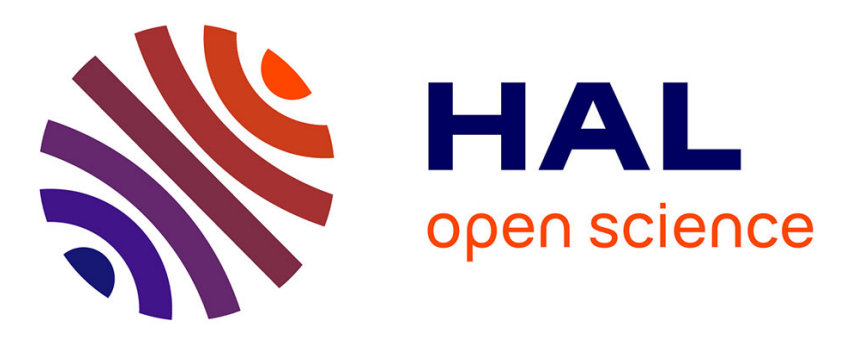

\title{
APRIL and TACI interact with syndecan-1 on the surface of multiple myeloma cells to form an essential survival loop.
}

Jérôme Moreaux, Anne-Catherine Sprynski, Stacey R. Dillon, Karène Mahtouk, Michel Jourdan, Arnaud Ythier, Philippe Moine, Nicolas Robert, Eric Jourdan, Jean François Rossi, et al.

\section{To cite this version:}

Jérôme Moreaux, Anne-Catherine Sprynski, Stacey R. Dillon, Karène Mahtouk, Michel Jourdan, et al. APRIL and TACI interact with syndecan-1 on the surface of multiple myeloma cells to form an essential survival loop.. European Journal of Haematology, 2009, 83 (2), pp.119-29. 10.1111/j.16000609.2009.01262.x . inserm-00397249

\section{HAL Id: inserm-00397249 https://www.hal.inserm.fr/inserm-00397249}

Submitted on 1 Apr 2010

HAL is a multi-disciplinary open access archive for the deposit and dissemination of scientific research documents, whether they are published or not. The documents may come from teaching and research institutions in France or abroad, or from public or private research centers.
L'archive ouverte pluridisciplinaire HAL, est destinée au dépôt et à la diffusion de documents scientifiques de niveau recherche, publiés ou non, émanant des établissements d'enseignement et de recherche français ou étrangers, des laboratoires publics ou privés. 


\section{APRIL AND TACI INTERACT WITH SYNDECAN-1 ON THE SURFACE OF MULTIPLE MYELOMA CELLS TO FORM AN ESSENTIAL}

\section{SURVIVAL LOOP}

Jérôme Moreaux, ${ }^{1,2}$ Anne-Catherine Sprynski, ${ }^{2}$ Stacey R. Dillon, ${ }^{3}$ Karène

Mahtouk, ${ }^{1,2}$ Michel Jourdan, ${ }^{2}$ Arnaud Ythier, ${ }^{5}$ Philippe Moine, ${ }^{1}$ Nicolas Robert, ${ }^{1}$ Eric Jourdan, ${ }^{2,6}$ Jean François Rossi, ${ }^{2,4,7}$ Bernard Klein ${ }^{1,2,7}$

${ }^{1} \mathrm{CHU}$ Montpellier, Institute of Research in Biotherapy, Montpellier, France;

${ }^{2}$ INSERM, U847, Montpellier, F-34197, France;

${ }^{3}$ ZymoGenetics, Seattle, WA, USA;

${ }^{4} \mathrm{CHU}$ Montpellier, Department of Haematology and Clinical Oncology, Montpellier,

France;

${ }^{5}$ Merck Serono International S.A., Geneva, Switzerland (an affiliate of Merck KGaA,

Darmstadt, Germany);

${ }^{6} \mathrm{CHU}$ Nîmes; Department of Haematology, Nîmes, France

${ }^{7}$ Université Montpellier 1, UFR Médecine, Montpellier, France.

\section{Corresponding author:}

Bernard Klein, INSERM U847, Institute for Research in Biotherapy, CHU Montpellier, Hospital St Eloi, Av. Augustin Fliche, 34285 Montpellier, France.

Phone: +334673378 88; fax: + 33467337905 .

E-mail: bernard.klein@montp.inserm.fr

Key words: Multiple myeloma, syndecan, APRIL, BAFF, BLyS

Running title: syndecan-1 promotes APRIL-TACI growth activity in myeloma cells 


\section{Abstract (181 words)}

BLyS and APRIL share two receptors - TACl and BCMA - and BLyS binds to a third receptor, BAFF-R. We previously reported that $T A C /$ gene expression is a good indicator of a BLyS-binding receptor in human multiple myeloma cell lines (HMCLs), unlike BCMA, which is expressed by all HMCLs or BAFF-R which is typically not expressed by late-stage B cells. We hypothesized a link between APRIL and TACI through syndecan-1, similar to the situation reported for FGF and FGFR. We observed very strong binding of APRIL, but not BLyS, at the surface of all syndecan $-1^{+} \mathrm{HMCLs}$ and primary multiple myeloma cells (MMC). All syndecan- $1^{+}$HMCLs and MMC could also bind TACI-Fc, but not BCMA-Fc or BAFF-R-FC molecules. Binding of APRIL or TACI-Fc was abrogated by heparin or cell pre-treatment with heparitinase, which cleaves heparan sulfate chains. The growth factor activity of APRIL on MMC was also inhibited by heparin. Our data identify syndecan-1 as a co-receptor for APRIL and $\mathrm{TACl}$ at the cell surface of MMC, promoting the activation of an APRIL/TACl pathway that induces survival and proliferation in MMC. 


\section{Introduction}

Multiple myeloma (MM) is a fatal plasma cell neoplasia associated with anaemia, osteolytic bone lesions and renal failure. This disease still remains incurable, despite major treatment improvements including high-dose chemotherapy and stem cell transplantation, Velcade ${ }^{\circledR}$, thalidomide and thalidomide derivatives as Lenalidomide ${ }^{\circledR}$ [1]. Several growth factors are involved in the growth and survival of multiple myeloma cells (MMC): interleukin 6 (IL-6) and its agonist soluble IL-6 receptor [2; 3], insulin like growth factor-1 (IGF-1) [4], hepatocyte growth factor (HGF) [5], interferon alpha [6], members of the epidermal growth factor (EGF) family [7; 8], IL-10 [9], tumour necrosis factor (TNF) [10], the wnt family [11], B-cell activating factor of the TNF family (BLyS) and a proliferation-inducing ligand (APRIL) [12; 13].

APRIL and BLyS are two members of the TNF family that bind to the TNFR-like receptors $\mathrm{TACl}$ (transmembrane activator and calcium modulator and cyclophilin ligand interactor) and BCMA (B-cell maturation antigen). BLyS also binds to BAFF receptor (BAFFR) [14]. Using Affymetrix microarrays, we previously demonstrated that the $T A C l$ and $B C M A$ genes were over-expressed in MMC compared with their normal counterparts [13]. BLyS is involved in the survival of normal and malignant B cells and normal plasmablasts. APRIL is highly expressed in various tumours and stimulates the growth of tumour cells [15]. In patients with MM, BLyS and APRIL are mainly produced by the bone marrow microenvironment, in particular myeloid cells, monocytes and osteoclasts [16]. BLyS and APRIL are growth factors for MMC in vitro [12; 13] but also in an in vivo murine model [17]. The activation of nuclear factor (NF)-KB by TACl, BCMA and BAFF-R [18] is consistent with the anti-apoptotic role of BLyS, as NFKB enhances the expression of several cell survival genes $[19 ; 20]$. Depending on the B-cell maturation stage, BLyS has been reported to induce the anti-apoptotic proteins $\mathrm{Bcl}-2, \mathrm{~A} 1$, and $\mathrm{Bcl}-\mathrm{XL}$ and to reduce the pro-apoptotic protein Bak [18; 21; 22]. BLyS also activates Jun N-terminal kinase (JNK), Elk-1, p38 kinase, AP-1 and NF-AT in various models [14]. In MMC, BLyS and APRIL activate MAPK, PI3K/AKT and $\mathrm{NF \kappa B}$ pathways, leading to an up-regulation of $\mathrm{Mcl}-1$ and $\mathrm{Bcl}-2$ anti-apoptotic proteins [13]. 
Recently, Tai et al. have shown that MMC express BCMA and $\mathrm{TACl}$, but very low levels of BAFF-R [23]. They demonstrated that BLyS induces the activation of NFKB and PI3K/AKT pathways, confirming our previous results [13]. Furthermore, this group showed that BLyS could activate the canonical and the non-canonical NFKB pathways in MMC. Of note, several genes coding for NFKB pathway proteins are abnormal in MMC of $20 \%$ of the newlydiagnosed patients, leading to hyper-activation of the NFKB pathway [24; 25]. In particular, an amplification of the $T A C /$ gene was reported in some MMC leading to NFKB pathway upregulation $[24 ; 25]$.

Ingold et al. and Hendriks et al. have demonstrated that APRIL can bind to heparan sulfate (HS) chains and this binding can be inhibited by heparin [26; 27]. This may explain why APRIL can bind cell lines that do not express BCMA or TACl, by binding to a cellsurface proteoglycan (PG) with HS chains. B-cell lymphomas also bind high levels of neutrophil-secreted APRIL via surface PGs, and high expression of APRIL in the tumour lesions correlates with B-cell lymphoma aggressiveness [28]. Binding of APRIL to HS chains occurs via the lysine-rich region in its N-terminal portion, which leaves its TNF-like region free to interact with the BCMA and TACl receptors. Of note, TACI-Fc binds also to $\mathrm{HS}$ chains, in particular to syndecan-1, syndecan-2 and syndecan-4 [29].

Syndecan-1 is involved in numerous interactions with extracellular matrix proteins, growth factors, chemokines and adhesion molecules through its HS chains [30]. In the bone marrow, syndecan-1 is expressed by normal plasma cells and is highly expressed by the majority of malignant plasma cells in patients with MM [31]. We have recently demonstrated that syndecan-1 is essential for myeloma cell growth factor (MGF) activity of EGF-family members [32] and the same holds true for HGF MGF activity [5].

In the present study, we demonstrate that MMC can bind high amounts of APRIL and soluble TACI through cell surface syndecan-1, and that this binding to syndecan-1 is critical for APRIL myeloma cell growth and survival. 
Materials and methods

\section{Cell samples}

XG-1, XG-2, XG-3, XG-4, XG-5, XG-6, XG-7, XG-10, XG-11, XG-12, XG-13, XG-16, and XG-20 human myeloma cell lines (HMCLs) were obtained from patients with extramedullary disease in our laboratory [33; 34]. SKMM, OPM2, LP1, L363 and RPMI8226 HMCLs were purchased from ATTC (Rockville, MD). Primary MMC were purified from patients with MM at diagnosis, after written informed consent was given, as indicated [8].

\section{$B C M A, T A C I$ and BAFF-R expression}

The expression of BCMA, TACl and BAFF-R at the cell surface of HMCLs was determined via fluorescence-activated cell sorting (FACS) analysis using biotinylated anti-BCMA, antiTACl, anti-BAFF-R monoclonal antibodies (MoAbs) (provided by ZymoGenetics Inc., Seattle, WA), biotynilated isotype-matched control MoAb (Beckman-Coulter; Marseilles, France), and phycoerythrin-conjugated streptavidin (PE-streptavidin, Beckman-Coulter). BCMA, TACI and

BAFF-R expression on primary MMC was determined using a double labelling with a fluorescein isothiocyanate (FITC)-conjugated anti-CD138 MoAb [35], biotinylated antiBCMA, anti-TACl, anti-BAFF-R MoAb, or isotype-matched control MoAb and PEstreptavidin.

\section{Proliferation assay}

HMCLs were IL-6 starved for 3 hours and cultured for 4 days in 96-well, flat-bottomed microtitre plates at $10^{4}$ cells per well in RPMI 1640 medium with $5 \%$ fetal calf serum, with or without IL-6 (3 ng/mL; Peprotech, Rocky Hill, NJ), BLyS (200 ng/mL; Peprotech) or APRIL (200 ng/mL; R\&D Systems, Abingdon, United Kingdom) in the presence or absence of dexamethasone (DEX, $\left.10^{-6} \mathrm{M}\right)$ and heparin $(4 \mathrm{IU} / \mathrm{ml})$. We used a growth assay to assess cell numbers at the end of the culture by quantifying intracellular adenosine triphosphate amounts with the Cell Titer Glo ${ }^{\circledR}$ Luminescent Assay (Promega Corporation, Madison, USA). 
The luciferase measurement was done by a Centro LB 960 luminometer (Berthold Technology, Germany).

\section{Detection of growth factor/growth factor receptor binding by FACS}

Cells were incubated with $1 \mu \mathrm{g} / \mathrm{mL}$ of APRIL or BLyS for 1 hour at $37^{\circ} \mathrm{C}$ and washed twice in phosphate-buffered saline before incubation with biotinylated anti-BLyS (provided by ZymoGenetics Inc., Seattle, WA), anti-APRIL (Peprotech, Rocky Hill, NJ) or isotype-matched control, antibodies and PE-streptavidin. Cells were also incubated with TACl-Fc, BCMA-Fc, BAFF-R-Fc or control human immunoglobulin (lg) (R\&D Systems) and then with biotinylated anti-TACl, anti-BCMA or anti BAFF-R MoAbs or biotinylated isotype-matched control MoAbs and PE-streptavidin. The fluorescence was determined using a FACSCalibur ${ }^{\mathrm{TM}}$ fluorescence activated cytometer (Becton Dickinson; San Jose, CA). To specifically inhibit binding between HS chains and growth factors, added APRIL, BLyS, TACI-Fc, BCMA-Fc or BAFFR-Fc were pre-incubated with $4 \mathrm{IU} / \mathrm{ml}$ heparin for 1 hour at $37^{\circ} \mathrm{C}$. To cleave the HS chains, MMC were pre-treated with $10 \mathrm{mU} / \mathrm{ml}$ heparitinase (Sigma; St Louis, MO) for 1 hour at $37^{\circ} \mathrm{C}$. Binding of BLyS or APRIL at the surface of primary MMC was detected after incubation of MMC with APRIL, BLyS, TACI-Fc, BCMA-Fc or BAFF-R-Fc using a double labelling with a FITC-conjugated anti-CD138 MoAb and biotinylated anti-BLyS, anti-APRIL, anti-TACI, antiBCMA or anti-BAFF-R MoAbs and PE-streptavidin.

\section{Real-time reverse transcriptase polymerase chain reaction}

Total RNA was converted to cDNA using the Superscript ${ }^{T M}$ \| reverse transcriptase (RT; Invitrogen, Cergy Pontoise, France). The Assays-On-Demand ${ }^{\mathrm{TM}}$ primers and probes, and the $\operatorname{TaqMan}^{\circledR}$ Universal Master Mix were used according to the manufacturer's instructions (Applied Biosystems, Courtaboeuf, France). Measurement of gene expression was performed using the ABI Prism ${ }^{\circledast} 7000$ Sequence Detection System. Quantitative polymerase chain reaction (PCR) analysis was completed using $A B I$ Prism ${ }^{\circledR} 7000$ SDS Software. For each primer, serial dilutions of a standard cDNA were amplified to create a standard curve, 
and values of unknown samples were estimated relative to this standard curve in order to assess the PCR efficiency. Threshold cycle (Ct) values were collected for glyceraldehyde-3phosphate dehydrogenase (GAPDH) and the genes of interest during the log phase of the cycle. Gene-of-interest levels were normalized to GAPDH for each sample ( $\delta \mathrm{Ct}=\mathrm{Ct}$ gene of interest - Ct GAPDH) and compared with the values obtained for a known positive control using the following formula: $100 / 2^{\delta \delta \mathrm{Ct}}$ where $\delta \delta \mathrm{Ct}=\delta \mathrm{Ct}$ unknown $-\delta \mathrm{Ct}$ positive control.

\section{Statistical analysis}

Statistical significance was tested using a non-parametric Wilcoxon test for pairs or a Student's $t$ test for pairs. 


\section{Results}

\section{Expression of specific BLyS/APRIL receptors on myeloma cells}

FACS analysis of $16 \mathrm{HMCLs}$ demonstrated that none of these lines express cell-surface BAFF-R, whereas BAFF-R is expressed on the Raji B-cell line (Figure 1). In agreement, a 100 to 1000 lower BAFF-R gene expression was found in HMCLs (0.1 to 1 arbitrary units) compared with Raji B cells (100 arbitrary units) (supplementary data Figure S1). All HMCLs express BCMA on their surface (Figure 1). We showed previously using Affymetrix microarrays [16] that all of these HMCLs express BCMA gene, and this was confirmed here by real-time RT-PCR (supplementary data Figure S1). TACI protein can be detected on seven out of the $16 \mathrm{HMCLS}$ (Figure 1). The TACl-negative HMCLs were previously shown to express no TAC/ gene using Affymetrix microarrays and real-time RT-PCR [16].

\section{Expression of non-specific APRIL receptor on myeloma cells}

Since APRIL binding can be observed on the surface of tumour cell lines that do not express the BLyS/APRIL receptors TACI or BCMA [15; 36], we looked for the binding of APRIL at the surface of MMC. Strong APRIL binding could be detected on all 15 syndecan- $1^{+}$HMCLs, including $\mathrm{TACl}^{+}$or $\mathrm{TACl}^{-} \mathrm{HMCLs}$. The mean fluorescence intensity (MFI) of labelling with APRIL-anti-APRIL MoAb ranged between 500 and 2000, i.e. 100-fold brighter than the labelling with BLyS-anti-BLyS MoAb on $\mathrm{TACl}^{+} \mathrm{HMCLs}$. Data for $10 \mathrm{HMCLs}$ are shown in Figure 2a. Only the syndecan-1 ${ }^{-}$XG-10 HMCL bind APRIL weakly with MFI of 10,10 to 100fold lower than those of syndecan- $1^{+}$HMCLs. This strong APRIL binding was abrogated by pre-treatment of APRIL with heparin, with a dramatic inhibition already observed with 0.1 $\mathrm{U} / \mathrm{mL}$ of heparin (Figure $2 \mathrm{~b}$ ). APRIL binding was also inhibited by pre-treatment of HMCLs with heparatinase from Flavobacterium heparinum that cleaves the HS side chains of heparan sulfate proteoglycans (HSPG) (Figure 2c). In these heparatinase-treated cells, a weak APRIL binding could still be detected, likely due to binding to specific BCMA and/or TACl receptors. Weak BLyS binding could be detected only on $\mathrm{TACl}^{+} \mathrm{HMCLs}$, unlike $\mathrm{TACl}^{-}$ 
HMCLs that all expressed membrane BCMA (Figure 2a), in agreement with our previous findings [16]. The weak binding of BLyS on $\mathrm{TACl}^{+} \mathrm{HMCLs}$ was not affected by heparin (Figure 2d). Thus, syndecan- $1^{+}$HMCLs express HSPG able to bind a very large number of APRIL molecules, but not BLyS molecules [26; 27]. As previously suggested by our group, this HSPG is likely syndecan-1, as of the 10 known HSPG, syndecan-1 is the major PG with HS chains expressed by MMC [32].

\section{Differential binding of TACI, BAFF-R and BCMA to syndecan-1}

As it was recently pointed out that TACl itself can bind syndecan HS [29], we investigated whether this is true also for syndecan- $1^{+}$MMC. All syndecan $-1^{+} \mathrm{HMCLs}$ bind TACI-Fc fusion protein (100\% labelling with MFI ranging from 20 to 1500). Data for 3 HMCLs are shown in Figure 3a. This TACI-Fc binding was abrogated by heparin pre-treatment or by pretreatment of MMC with heparatinase (Figure 3a). No binding of BCMA-Fc or BAFF-R-FC molecules to HMCLs could be detected (Figure 3b).

\section{Growth factor activity of APRIL and BLyS}

To demonstrate that the interaction of APRIL with syndecan-1 is important for its MGF activity, we used heparin as a competitor of HS chains in HMCL proliferation assays. We first used the XG-1 HMCL, whose growth is stimulated by APRIL, and showed that this stimulation is abrogated by a TACI-Fc fusion protein (Figure 4a). Heparin also abrogated the growth factor activity of APRIL in agreement with APRIL HSPG binding activity. Neither TACI-Fc nor heparin blocks the growth factor activity of IL-6 on XG-1 cells (Supplementary data Figure S2). BLyS had no growth-promoting activity on the $\mathrm{TACl}^{-} \mathrm{XG}-1 \mathrm{HMCL}$, in agreement with the lack of binding of BLyS already documented in this $\mathrm{TACl}^{-} \mathrm{HMCL}$ [16] and as in Figure 2a. BLyS or APRIL can protect MMC from the apoptosis induced by DEX, a potent drug for MM treatment [13]. As indicated in Figure 4b, DEX induced apoptosis in the $\mathrm{TACl}^{+}$L363 and LP1 HMCLs. Both BLyS and APRIL significantly protected the L363 ( $P=.0001$ and $P=.01 ; n=5$, respectively) and LP1 $(P=.0001$ and $P=.003 ; n=5$, respectively) 
HMCLs from DEX-induced apoptosis (Figure 4b). TACI-Fc abrogated the protective effect of BLyS and APRIL, and heparin abolished that of APRIL, but not that of BLyS (Figure 4b).

\section{Expression of BLyS/APRIL receptors on primary $M M C$}

We tested primary MMC of 22 consecutive newly-diagnosed patients with MM for membrane expression of the three BLyS APRIL receptors and their ability to bind a BLyS-murineCD8 fusion protein (Table 1). Using anti-receptor MoAbs and FACS analysis, BCMA, TACI and BAFF-R were detected on primary MMC of 19,15 and 17 out of 22 patients, respectively (Table 1). Binding of the BLyS-murineCD8 fusion protein was detected in $12 / 22$ patients. As reported previously [16; 37], BLyS-murineCD8 binding to primary MMC strongly correlated with TACl expression $(r=.9, P<.01)$. The correlation coefficients between BCMA or BAFF-R expression and BLyS-murineCD8 labelling were $r=.6(P<.01)$ and $r=.7(P<.01)$, respectively. TACl and BCMA expression $(r=.7 ; P<.01)$ and TACl and BAFF-R $(r=.5 ; P<.05)$ were significantly correlated, whereas no correlation was found between BCMA and BAFF-R expression. As reported for HMCLs, strong binding of APRIL was found on primary MMC of five newly diagnosed patients (Figure 5a). The MFI ranged from 1000 to 5000 . In comparison, BLyS weakly bound to primary $\mathrm{TACl}^{+} \mathrm{MMC}$ with a MFI that was 10 - to 100 -fold lower (Figure 5b). A subset of primary MMC also bound TACI-Fc molecules, but did not bind BCMA-Fc or BAFF-R-Fc (Figure 5c). 


\section{Discussion}

Given the important role of BLyS and APRIL as MGFs [12; 13; 17], we investigated the expression of their receptors on HMCLs and MMC. We found that MMC variably expressed the three specific receptors - BCMA, BAFF-R and TACI - and expressed syndecan-1 as a co-receptor for APRIL and TACI, but not for BCMA, BLyS, or BAFF-R.

BCMA was expressed by virtually all MMC, including those of 19/22 newly-diagnosed patients and of $16 / 16$ HMCLs. This is in agreement with data in mice showing that BCMA is mandatory for plasma cell differentiation [38]. Indeed, a knockout of the BCMA gene abrogated plasma cell generation, unlike knockouts of the BAFF-R or TACl genes [38]. Regarding BAFF-R, we confirmed and extended our previous real time RT-PCR data showing a lack of BAFF-R RNA and protein in 16/16 HMCLs. However, by contrast, BAFF-R was found to be expressed by primary MMC of $17 / 22$ patients (Table 1). There are two possible explanations for this discrepancy. First, HMCLs are obtained from a small number of patients with extramedullary proliferation [39] in whom BAFF-R expression could be lost on MMC. BAFF-R expression may be dispensable for HMCLs growth in vitro but may be necessary for MMC growth in vivo. Another explanation is that the bone marrow tumour environment might trigger BAFF-R in primary MMC. This is unlikely because we failed to induce BAFF-R expression by incubating HMCLs together with bone marrow cells from patients with $\mathrm{MM}$ (results not shown). Regarding the TACI receptor, we previously reported that $T A C /$ gene expression is clear cut in HMCLs, being either present or absent using real time RT-PCR or Affymetrix microarrays [37]. This was confirmed by staining HMCLs with anti-TACI MoAb. TACl gene expression was less clear cut in primary MMC, as TACl was expressed in MMC from all patients tested [16], and TACl protein was detected in primary MMC of $15 / 22$ patients. Using HMCLs, we found that the ability to bind CD8-BLyS was related to TACl expression in seven of 16 HMCLs [16; 37]. We can exclude here a previous hypothesis suggesting a possible retention of BCMA in the Golgi apparatus [40] as all HMCLs expressed membrane BCMA. The lack of binding of BLyS on BCMA ${ }^{+} / \mathrm{TACl}^{-} \mathrm{HMCLS}$ might be explained by the 1000 -fold reduced affinity of BLyS for BCMA compared with that 
of APRIL [41]. In primary MMC, BLyS binding was also strongly correlated with TACI protein expression, and more weakly correlated with expression of BAFF-R. Thus the present data indicate that although BCMA is expressed at the cell surface of MMC, it is unable to bind BLyS trimers with a sufficient affinity, which may explain the lack of BLyS activity on BCMA $\mathrm{TACl}^{-} \mathrm{HMCLs}$. Regarding, BCMA, TACl and BAFF-R expression using the University of Arkansas School of medical Sciences data set (TT2 cohort of 345 patients), BCMA had a "present" Affymetrix call in 345/345 of primary MMC investigated, TACl in 273/345 and $B A F F-R$ had an "absent" Affymetrix call in $345 / 345$ of primary MMC investigated. We looked for a prognostic relevance of $\mathrm{BCMA}$ or $\mathrm{TACl}$ expression. We considered subgroup defined by $50 \%$ of the patients with the highest or lowest BCMA or TACl expression in MMC. Neither BCMA nor TACl expression were associated with prognosis in this large cohort of patients (data not shown).

In contrast to Blys, APRIL induced proliferation of $\mathrm{BCMA}^{+} / \mathrm{TACl}^{-} \mathrm{HMCLs}$. This observation is substantiated by the observed strong binding of APRIL to both HMCLs and primary MMC, with a MFI ranging from 500 to 5000 for the HMCLs and primary MMC. APRIL binding was mediated through a HSPG, since it is abrogated by heparitinase pre-treatment of cells, in agreement with previous studies [26; 27]. Similar findings were described for HGF [5] or HS-binding EGF family members [32]. Regarding HS-binding EGF members, MFI (1000-5000) similar to that of APRIL were obtained, and we determined that several hundred thousand EGF molecules bound to a MMC cell membrane via a HSPG. Syndecan-1 is the major PG with HS chains expressed by MMC, as other HSPG, including glypican family members and syndecan-2, -3 and -4 were not expressed or expressed at a lower level by most MMC samples [32]. We therefore speculate that MMC can bind several hundred thousand APRIL molecules through syndecan-1 as this was estimated previously for amphiregulin or HB-EGF binding to MMC [42].

The importance of syndecan-1 in promoting APRIL activity is reinforced by the observation that MMC also largely bound soluble TACl-Fc through syndecan-1, but did not bind BAFF-R-Fc or BCMA-Fc. Although binding of membrane-bound $\mathrm{TACl}$, was not shown 
in this study, Bischof et al. demonstrated selective activation of TACl by syndecan-1, -2 and 4. In the case of fibroblast growth factor (FGF), syndecan-1 can simultaneously bind both FGF and its receptor, thus facilitating binding of FGF to its specific receptor [43; 44]. Thus our present findings emphasize that syndecan-1 can confer a specific bridge to mediate an APRIL-TACI loop in the biology of MMC. This is consistent with the finding that primary MMC which highly express $\mathrm{TACl}\left(\mathrm{TACl}^{\text {high }}\right)$ have a gene signature indicative of an interaction with the bone marrow environment, whereas $\mathrm{TACl}^{\text {low }} \mathrm{MMC}$ have a bone marrow-independent plasmablastic gene signature [16]. This characteristic was not found for BCMA ${ }^{\text {high }} M M C$ and $\mathrm{BCMA}^{\text {low }} \mathrm{MMC}$, and was kept in HMCLs [37]. APRIL is not produced by the actual primary $\mathrm{MMC}$, but rather by the bone marrow environment, including monocytes and osteoclasts [16]. Thus we postulate the existence of a three-way interaction in the bone niche that includes osteoclasts, osteoblasts and mesenchymal cells. In this scenario, APRIL is largely produced by osteoclasts [16; 45], is captured by soluble and membrane syndecan-1 HS chains through the lysine-rich region in the N-terminal portion of APRIL, and is then presented to the TACl receptor, which also binds syndecan-1 HS chains. In support of this theory, we have also shown that osteoclasts express heparanase [46], which can cleave HS chains into bioactive $10-20$ polysaccharides that can enable the presentation of APRIL to TACl.

Our observation is further supported by the recent results of Yaccoby et al., who demonstrated that TACI-Fc inhibits growth of $\mathrm{TACl}^{\text {high }} \mathrm{MMC}$ in $\mathrm{MMC} /$ osteoclasts co-cultures [17]. Furthermore, they showed that $\mathrm{TACl}-\mathrm{Fc}$ treatment markedly reduced the growth of $\mathrm{TACl}^{\text {high }}$ primary MMC in SCID-Hu xenografted mice. In contrast, treatment with BAFF-R-FC, which binds BLyS but not APRIL, did not significantly inhibit the growth of MMC in vivo [17]. Taken together, the data indicate that the concentration of APRIL and TACI at the MMC cell membrane in close proximity with syndecan-1 defines an APRIL/TACI signalling loop that apparently plays an essential role in MM biology.

Regarding the signalling pathway involved in this process, we and others have shown that BLyS and APRIL can strongly activate the canonical [13] as well the non 
canonical NF-KB pathways $[47 ; 48]$. By comparison, IL-6 or IGF-1 only slightly activate the NF-KB pathways. Our current findings demonstrating the importance of syndecan-1 in APRIL/TACI signalling are reinforced by two recent studies describing a promiscuous array of genetic alterations yielding to activation of NF-KB pathway in approximately $20 \%$ of MM patients and $41 \%$ of HMCLs $[24 ; 25]$. These alterations include overexpression and/or gainof-function mutations in NIK, NFKB2, NFKB1, CD40, LTBR and TACl, all genes coding for proteins activating the NF- $\mathrm{BB}$ pathway. These alterations also include inactivating abnormalities of TRAF3, CIAP1, CIAP2, CYLD and TRAF2, which are negative regulators of $N F-\kappa B$. These two studies disagree on whether the canonical or non canonical NF-kB pathways are predominantly dysregulated. Of note, Annunziata et al. [24] clearly demonstrated that activation of NIK affected both the canonical and non canonical pathways. In addition, Keats et al reported that DEX was poorly efficient compared to bortezomib in patients with NF-KB alterations whereas both therapies were efficient in other patients[25]. Thus, we speculate that in the patients with NF-KB alterations, there is an increased activation of the NF-KB pathway, possibly through osteoclast- and monocyte-producedAPRIL that is heavily concentrated at a large concentration at the surface of MMC through its interaction with syndecan-1 HS chains.

These observations underscore the potential value of using BLyS/APRIL inhibitors in the treatment of at least a subset of patients with MM. We recently completed a phase I-II clinical trial of Atacicept (formerly known as TACl-Fc5), which demonstrated the feasibility and safety of BLyS/APRIL targeting in MM and Waldenstrom's macroglobulinemia patients [49]. It may further prove interesting to combine BLyS/APRIL inhibitors with NF-KB inhibitors [50] in patients with NF-KB alterations. In addition, low molecular weight heparin injections favourably influence the survival in patients with advanced epithelial malignancies, whose tumor cells largely express syndecan [51]. Thus APRIL signaling should be considered as a potential target for a combination of specific BAFF/APRIL inhibitor and heparin. 


\section{Acknowledgements}

This work was supported by grants from the Ligue Nationale Contre le Cancer (équipe labellisée 2009), Paris, France, from INCA ( ${ }^{\circ}$ R07001FN) and from MSCNET European strep ( $\left.{ }^{\circ} \mathrm{E} 06005 \mathrm{FF}\right)$.

\section{Author contributions}

JM designed research, performed the experiments and wrote the paper.

EJ and JFR collected bone marrow samples and clinical data.

ACS, KM, MJ, PM and NR participated in some of the experiments.

AY and SRD provided reagents and reviewed the paper.

$\mathrm{BK}$ is the senior investigator who designed research and wrote the paper. 
Table 1: Ability of MMC to bind recombinant BLyS and expression of BCMA, TACI and BAFF-R on primary MMC. BLyS binding was determined using a double labelling of primary MMC with a FITC-conjugated anti-CD138 MoAb, human BLyS-muCD8 biotinylated fusion protein and PE-streptavidin. BCMA, TACl and BAFF-R expression was determined using a double labelling of primary MMC with a FITC-conjugated anti-CD138 MoAb, biotinylated antiBCMA, anti-TACI or anti-BAFF-R MoAb, and PE-streptavidin. The background fluorescence was determined with biotinylated isotype-matched control MoAbs and set at a MFI of 3-8. A percentage $\leq 5 \%$ was considered negative.

\begin{tabular}{|c|c|c|c|c|}
\hline $\begin{array}{c}\text { Reference for } \\
\text { patients with } \\
\text { newly-diagnosed } \\
\text { MM }\end{array}$ & $\begin{array}{c}\text { CD8-BLyS } \\
\text { binding } \\
(\%)\end{array}$ & $\begin{array}{c}\text { BCMA } \\
\text { expression } \\
(\%)\end{array}$ & $\begin{array}{c}\text { TACl } \\
\text { expression } \\
(\%)\end{array}$ & $\begin{array}{c}\text { BAFF-R } \\
\text { expression } \\
(\%)\end{array}$ \\
\hline 1 & $\leq 5$ & 39 & $\leq 5$ & $\leq 5$ \\
\hline 2 & $\leq 5$ & 35 & $\leq 5$ & 22 \\
\hline 3 & 54 & 95 & 87 & 9 \\
\hline 4 & $\leq 5$ & 9 & $\leq 5$ & 21 \\
\hline 5 & 87 & 56 & 95 & 71 \\
\hline 6 & $\leq 5$ & $\leq 5$ & $\leq 5$ & $\leq 5$ \\
\hline 7 & 5 & 55 & 10 & 6 \\
\hline 8 & $\leq 5$ & 18 & $\leq 5$ & 40 \\
\hline 9 & $\leq 5$ & 20 & 33 & 13 \\
\hline 10 & 33 & 22 & 31 & 66 \\
\hline 11 & $\leq 5$ & 14 & 14 & 14 \\
\hline 12 & 7 & $\leq 5$ & 5 & $\leq 5$ \\
\hline 13 & 10 & 38 & 11 & 11 \\
\hline 14 & 28 & 78 & 85 & 9 \\
\hline 15 & $\leq 5$ & 79 & 8 & 28 \\
\hline 16 & 27 & 31 & 20 & 69 \\
\hline 17 & $\leq 5$ & $\leq 5$ & $\leq 5$ & $\leq 5$ \\
\hline 18 & 96 & 95 & 89 & 99 \\
\hline 19 & $\leq 5$ & 33 & 9 & 12 \\
\hline 20 & 88 & 79 & 98 & 98 \\
\hline 21 & 13 & 24 & $\leq 5$ & $\leq 5$ \\
\hline 22 & 15 & 18 & 15 & 60 \\
\hline
\end{tabular}




\section{Figure Legends}

Figure 1. Cell membrane and gene expression of TACI, BCMA and BAFF-R by HMCLs: Cell surface expression of TACI, BCMA and BAFF-R was determined by flow cytometry using biotinylated anti-TACl, anti-BCMA or anti-BAFF-R MoAb, and PE-streptavidin. The Raji cell line was used as a control. Open histograms show the staining obtained with anti-TACl, antiBCMA or anti-BAFF-R MoAbs. Black histograms represent the fluorescence signal obtained with the control MoAb.

Figure 2. Strong binding of APRIL at the cell membrane of HMCLs through HS chains: (a) Binding of APRIL or BLyS at the cell membrane of $10 \mathrm{HMCLs}\left(5 \mathrm{TACl}^{+} \mathrm{HMCLs}\right.$ and $5 \mathrm{TACl}^{-}$ HMCLs) was determined by flow cytometry. Cells were incubated with $1 \mu \mathrm{g} / \mathrm{mL}$ of APRIL or BLyS, washed and then labelled with a biotinylated anti-APRIL or anti-BLyS MoAb and PEstreptavidin. Open histogram shows the fluorescence intensity with anti-APRIL or anti-BLyS MoAb. Black histogram indicates the staining obtained from the control MoAb; (b) To demonstrate the involvement of HS chains in APRIL binding, APRIL was pre-incubated with graded concentrations of heparin and APRIL binding to L363 HMCL was assessed by flow cytometry. Open histograms show the fluorescence intensity with the anti-APRIL MoAb and black histograms show that obtained with the control MoAb; (c) APRIL was pre-incubated with $4 \mathrm{IU} / \mathrm{mL}$ of heparin before assaying its binding to HMCLs. MMC were also pre-treated with $10 \mathrm{mU} / \mathrm{ml}$ heparatinase from Flavobacterium heparinum which specifically cleaves the HS chains, and the binding of APRIL to HMCLs was analysed. Open histograms show the fluorescence intensity obtained with the anti-APRIL MoAb and black histograms show that obtained with the control MoAb; (d) BLyS was first pre-incubated with $4 \mathrm{IU} / \mathrm{mL}$ of heparin before assaying its binding to HMCLs using a biotinylated anti-BLyS MoAb and PEstreptavidin. Open histogram shows the fluorescence intensity obtained with the anti-BLyS MoAb and black histogram shows that obtained with a control MoAb.

Figure 3. Binding of $\mathrm{TACl}$ at the surface of HMCLs through HS chains: (a) TACl-FC (1 $\mu \mathrm{g} / \mathrm{mL}$ ) were pre-incubated with $4 \mathrm{IU} / \mathrm{ml}$ heparin before assaying its binding on HMCLs. MMC were also pre-treated with $10 \mathrm{mU} / \mathrm{ml}$ heparatinase to cleave the HS chains before assaying binding of TACl-Fc. Open histogram shows the fluorescence obtained with TACl-Fc and the black histograms show those with control Fc; (b) Binding of BCMA-FC and BAFF-R-Fc fusion proteins at the surface of HMCLs was determined by flow cytometry. Cells were incubated with $1 \mu \mathrm{g} / \mathrm{mL}$ of BCMA-Fc or BAFF-R-Fc or control human Ig before incubation with anti- 
BCMA or anti-BAFF-R MoAbs. The open histograms indicate the fluorescence obtained with BCMA-FC or BAFF-R-Fc molecules and the black histograms show those with control Ig.

Figure 4. Growth factor activity of BLyS and APRIL: (a) XG-1 HMCL was IL-6 starved for 3 hours and cultured without cytokine, or in the presence of BLyS $(200 \mathrm{ng} / \mathrm{ml})$ or APRIL (200 $\mathrm{ng} / \mathrm{ml})$, with or without TACl-Fc $(10 \mu \mathrm{g} / \mathrm{ml})$ or heparin $(4 \mathrm{lU} / \mathrm{ml})$. Results are the mean $( \pm \mathrm{SD})$ values of the RLU luminescence determined on sextuplet culture wells. Results shown are representative of five independent experiments. *The mean value is statistically significantly different from that obtained without cytokine (control) using Student's $t$-test $(p \leq .05)$. ${ }^{* \star}$ The mean value is statistically significantly different from that obtained with APRIL stimulation using Student's $t$ test ( $p \leq .05$ ); (b) L363 and LP1 HMCLs were cultured in the presence of $\operatorname{DEX}\left(10^{-6} \mathrm{M}\right)$ with or without IL-6 $(3 \mathrm{ng} / \mathrm{ml})$, or of BLyS $(200 \mathrm{ng} / \mathrm{ml})$ or APRIL $(200 \mathrm{ng} / \mathrm{ml})$ with or without TACl-Fc $(10 \mu \mathrm{g} / \mathrm{ml})$ or heparin $(4 \mathrm{IU} / \mathrm{ml})$. Results are the mean $( \pm S D)$ values of the RLU fluorescence determined on sextuplet culture wells. Results shown are representative of five independent experiments. * The mean value is statistically significantly different from that obtained without DEX (control) using Student's $t$-test $(p \leq .05)$. ${ }^{* *}$ The mean value is statistically significantly different from that obtained with DEX treatment using Student's $t$-test $(p \leq .05)$.

Figure 5. Expression of BLyS/APRIL receptors on primary myeloma cells: (a-b) Binding of APRIL or BLyS at the surface of primary MMC of five patients was determined by flow cytometry. Cells were incubated with $1 \mu \gamma / \mathrm{mL}$ of APRIL or BLyS, washed and the binding of ligand was determined with a double labelling of primary MMC with an anti-CD138 and an anti-APRIL MoAb or with an anti-CD138 and an anti-BLyS MoAb; (c) Binding of TACI-Fc, BCMA-Fc and BAFF-R-Fc fusion proteins at the surface of primary MMC was determined by flow cytometry. Cells were incubated with $1 \mu \mathrm{g} / \mathrm{mL}$ of TACI-Fc, BCMA-Fc or BAFF-R-Fc or a control human Ig before double labelling of primary MMC with an anti-CD138 MoAb and an anti-TACl, anti-BCMA or anti-BAFF-R MoAb. 


\section{References}

[1] J.R. Berenson, and O. Yellin, New drugs in multiple myeloma. Curr Opin Support Palliat Care 2 (2008) 204-10.

[2] X.G. Zhang, R. Bataille, J. Widjenes, and B. Klein, Interleukin-6 dependence of advanced malignant plasma cell dyscrasias. Cancer 69 (1992) 1373-6.

[3] J.P. Gaillard, J. Liautard, B. Klein, and J. Brochier, Major role of the soluble interleukin6/interleukin-6 receptor complex for the proliferation of interleukin-6-dependent human myeloma cell lines. Eur J Immunol 27 (1997) 3332-40.

[4] M. Ferlin, N. Noraz, C. Hertogh, J. Brochier, N. Taylor, and B. Klein, Insulin-like growth factor induces the survival and proliferation of myeloma cells through an interleukin6-independent transduction pathway. Br J Haematol 111 (2000) 626-34.

[5] P.W. Derksen, R.M. Keehnen, L.M. Evers, M.H. van Oers, M. Spaargaren, and S.T. Pals, Cell surface proteoglycan syndecan-1 mediates hepatocyte growth factor binding and promotes Met signaling in multiple myeloma. Blood 99 (2002) 1405-10.

[6] M. Ferlin-Bezombes, M. Jourdan, J. Liautard, J. Brochier, J.F. Rossi, and B. Klein, IFNalpha is a survival factor for human myeloma cells and reduces dexamethasoneinduced apoptosis. J Immunol 161 (1998) 2692-9.

[7] K. Mahtouk, D. Hose, T. Reme, J. De Vos, M. Jourdan, J. Moreaux, G. Fiol, M. Raab, E Jourdan, V. Grau, M. Moos, H. Goldschmidt, M. Baudard, J.F. Rossi, F.W. Cremer, and B. Klein, Expression of EGF-family receptors and amphiregulin in multiple myeloma. Amphiregulin is a growth factor for myeloma cells. Oncogene 24 (2005) 3512-24.

[8] K. Mahtouk, M. Jourdan, J. De Vos, C. Hertogh, G. Fiol, E. Jourdan, J.F. Rossi, and B. Klein, An inhibitor of the EGF receptor family blocks myeloma cell growth factor activity of HB-EGF and potentiates dexamethasone or anti-IL-6 antibody-induced apoptosis. Blood 103 (2004) 1829-37.

[9] Z.J. Gu, V. Costes, Z.Y. Lu, X.G. Zhang, V. Pitard, J.F. Moreau, R. Bataille, J. Wijdenes, J.F. Rossi, and B. Klein, Interleukin-10 is a growth factor for human myeloma cells by induction of an oncostatin M autocrine loop. Blood 88 (1996) 3972-86.

[10] M. Jourdan, K. Tarte, E. Legouffe, J. Brochier, J.F. Rossi, and B. Klein, Tumor necrosis factor is a survival and proliferation factor for human myeloma cells. Eur Cytokine Netw 10 (1999) 65-70.

[11] P.W. Derksen, E. Tjin, H.P. Meijer, M.D. Klok, H.D. MacGillavry, M.H. van Oers, H.M. Lokhorst, A.C. Bloem, H. Clevers, R. Nusse, R. van der Neut, M. Spaargaren, and S.T. Pals, Illegitimate WNT signaling promotes proliferation of multiple myeloma cells. Proc Natl Acad Sci U S A 101 (2004) 6122-7.

[12] A.J. Novak, J.R. Darce, B.K. Arendt, B. Harder, K. Henderson, W. Kindsvogel, J.A. Gross, P.R. Greipp, and D.F. Jelinek, Expression of BCMA, TACl, and BAFF-R in multiple myeloma: a mechanism for growth and survival. Blood 103 (2004) 689-94.

[13] J. Moreaux, E. Legouffe, E. Jourdan, P. Quittet, T. Reme, C. Lugagne, P. Moine, J.F. Rossi, B. Klein, and K. Tarte, BAFF and APRIL protect myeloma cells from apoptosis induced by interleukin 6 deprivation and dexamethasone. Blood 103 (2004) 3148-57.

[14] F. Mackay, P. Schneider, P. Rennert, and J. Browning, BAFF AND APRIL: A Tutorial on B Cell Survival. Annu Rev Immunol 21 (2003) 231-64.

[15] M. Hahne, T. Kataoka, M. Schroter, K. Hofmann, M. Irmler, J.L. Bodmer, P. Schneider, T. Bornand, N. Holler, L.E. French, B. Sordat, D. Rimoldi, and J. Tschopp, APRIL, a new ligand of the tumor necrosis factor family, stimulates tumor cell growth. J Exp Med 188 (1998) 1185-90.

[16] J. Moreaux, F.W. Cremer, T. Reme, M. Raab, K. Mahtouk, P. Kaukel, V. Pantesco, J. De Vos, E. Jourdan, A. Jauch, E. Legouffe, M. Moos, G. Fiol, H. Goldschmidt, J.F. Rossi, D. Hose, and $\mathrm{B}$. Klein, The level of TACl gene expression in myeloma cells is associated with a signature of microenvironment dependence versus a plasmablastic signature. Blood 106 (2005) 1021-30. 
[17] S. Yaccoby, A. Pennisi, X. Li, S.R. Dillon, F. Zhan, B. Barlogie, and J.D. Shaughnessy, Jr., Atacicept (TACl-lg) inhibits growth of TACl(high) primary myeloma cells in SCIDhu mice and in coculture with osteoclasts. Leukemia (2007).

[18] R.K. Do, E. Hatada, H. Lee, M.R. Tourigny, D. Hilbert, and S. Chen-Kiang, Attenuation of apoptosis underlies $B$ lymphocyte stimulator enhancement of humoral immune response. J Exp Med 192 (2000) 953-64.

[19] C. Chen, L.C. Edelstein, and C. Gelinas, The Rel/NF-kappaB family directly activates expression of the apoptosis inhibitor Bcl-x(L). Mol Cell Biol 20 (2000) 2687-95.

[20] W.X. Zong, L.C. Edelstein, C. Chen, J. Bash, and C. Gelinas, The prosurvival Bcl-2 homolog Bfl-1/A1 is a direct transcriptional target of NF-kappaB that blocks TNFalpha-induced apoptosis. Genes Dev 13 (1999) 382-7.

[21] M. Batten, J. Groom, T.G. Cachero, F. Qian, P. Schneider, J. Tschopp, J.L. Browning, and F. Mackay, BAFF mediates survival of peripheral immature B lymphocytes. J Exp Med 192 (2000) 1453-66.

[22] B.L. Hsu, S.M. Harless, R.C. Lindsley, D.M. Hilbert, and M.P. Cancro, Cutting edge: BLyS enables survival of transitional and mature B cells through distinct mediators. J Immunol 168 (2002) 5993-6.

[23] Y.T. Tai, X.F. Li, I. Breitkreutz, W. Song, P. Neri, L. Catley, K. Podar, T. Hideshima, D. Chauhan, N. Raje, R. Schlossman, P. Richardson, N.C. Munshi, and K.C. Anderson, Role of B-cell-activating factor in adhesion and growth of human multiple myeloma cells in the bone marrow microenvironment. Cancer Res 66 (2006) 6675-82.

[24] C.M. Annunziata, R.E. Davis, Y. Demchenko, W. Bellamy, A. Gabrea, F. Zhan, G. Lenz, I. Hanamura, G. Wright, W. Xiao, S. Dave, E.M. Hurt, B. Tan, H. Zhao, O. Stephens, M. Santra, D.R. Williams, L. Dang, B. Barlogie, J.D. Shaughnessy, Jr., W.M. Kuehl, and L.M. Staudt, Frequent engagement of the classical and alternative NF-kappaB pathways by diverse genetic abnormalities in multiple myeloma. Cancer Cell 12 (2007) 115-30.

[25] J.J. Keats, R. Fonseca, M. Chesi, R. Schop, A. Baker, W.J. Chng, S. Van Wier, R. Tiedemann, C.X. Shi, M. Sebag, E. Braggio, T. Henry, Y.X. Zhu, H. Fogle, T. PriceTroska, G. Ahmann, C. Mancini, L.A. Brents, S. Kumar, P. Greipp, A. Dispenzieri, B. Bryant, G. Mulligan, L. Bruhn, M. Barrett, R. Valdez, J. Trent, A.K. Stewart, J. Carpten, and P.L. Bergsagel, Promiscuous mutations activate the noncanonical NFkappaB pathway in multiple myeloma. Cancer Cell 12 (2007) 131-44.

[26] J. Hendriks, L. Planelles, J. de Jong-Odding, G. Hardenberg, S.T. Pals, M. Hahne, M. Spaargaren, and J.P. Medema, Heparan sulfate proteoglycan binding promotes APRIL-induced tumor cell proliferation. Cell Death Differ 12 (2005) 637-48.

[27] K. Ingold, A. Zumsteg, A. Tardivel, B. Huard, Q.G. Steiner, T.G. Cachero, F. Qiang, L. Gorelik, S.L. Kalled, H. Acha-Orbea, P.D. Rennert, J. Tschopp, and P. Schneider, Identification of proteoglycans as the APRIL-specific binding partners. J Exp Med 201 (2005) 1375-83.

[28] J. Schwaller, P. Schneider, P. Mhawech-Fauceglia, T. McKee, S. Myit, T. Matthes, J. Tschopp, O. Donze, F.A. Le Gal, and B. Huard, Neutrophil-derived APRIL concentrated in tumor lesions by proteoglycans correlates with human B-cell lymphoma aggressiveness. Blood 109 (2007) 331-8.

[29] D. Bischof, S.F. Elsawa, G. Mantchev, J. Yoon, G.E. Michels, A. Nilson, S.L. Sutor, J.L. Platt, S.M. Ansell, G. von Bulow, and R.J. Bram, Selective activation of TACl by syndecan-2. Blood 107 (2006) 3235-42.

[30] A.N. Alexopoulou, H.A. Multhaupt, and J.R. Couchman, Syndecans in wound healing, inflammation and vascular biology. Int J Biochem Cell Biol 39 (2007) 505-28.

[31] V. Costes, V. Magen, E. Legouffe, L. Durand, P. Baldet, J.F. Rossi, B. Klein, and J. Brochier, The Mi15 monoclonal antibody (anti-syndecan-1) is a reliable marker for quantifying plasma cells in paraffin-embedded bone marrow biopsy specimens. Hum Pathol 30 (1999) 1405-11.

[32] K. Mahtouk, F.W. Cremer, T. Reme, M. Jourdan, M. Baudard, J. Moreaux, G. Requirand, G. Fiol, J. De Vos, M. Moos, P. Quittet, H. Goldschmidt, J.F. Rossi, D. 
Hose, and B. Klein, Heparan sulphate proteoglycans are essential for the myeloma cell growth activity of EGF-family ligands in multiple myeloma. Oncogene (2006).

[33] C. Rebouissou, J. Wijdenes, P. Autissier, K. Tarte, V. Costes, J. Liautard, J.F. Rossi, J. Brochier, and B. Klein, A gp130 interleukin- 6 transducer-dependent SCID model of human multiple myeloma. Blood 91 (1998) 4727-37.

[34] X.G. Zhang, J.J. Gu, Z.Y. Lu, K. Yasukawa, G.D. Yancopoulos, K. Turner, M. Shoyab, T. Taga, T. Kishimoto, R. Bataille, and et al., Ciliary neurotropic factor, interleukin 11, leukemia inhibitory factor, and oncostatin $\mathrm{M}$ are growth factors for human myeloma cell lines using the interleukin 6 signal transducer gp130. J Exp Med 179 (1994) 1337-42.

[35] J. Wijdenes, W.C. Vooijs, C. Clement, J. Post, F. Morard, N. Vita, P. Laurent, R.X. Sun, B. Klein, and J.M. Dore, A plasmocyte selective monoclonal antibody (B-B4) recognizes syndecan-1. Br J Haematol 94 (1996) 318-23.

[36] P. Rennert, P. Schneider, T.G. Cachero, J. Thompson, L. Trabach, S. Hertig, N. Holler, F. Qian, C. Mullen, K. Strauch, J.L. Browning, C. Ambrose, and J. Tschopp, A soluble form of $B$ cell maturation antigen, a receptor for the tumor necrosis factor family member APRIL, inhibits tumor cell growth. J Exp Med 192 (2000) 1677-84.

[37] J. Moreaux, D. Hose, M. Jourdan, T. Reme, M. Hundemer, M. Moos, N. Robert, P. Moine, J. De Vos, H. Goldschmidt, and B. Klein, TACl expression is associated with a mature bone marrow plasma cell signature and C-MAF overexpression in human myeloma cell lines. Haematologica 92 (2007) 803-11.

[38] B.P. O'Connor, V.S. Raman, L.D. Erickson, W.J. Cook, L.K. Weaver, C. Ahonen, L.L. Lin, G.T. Mantchev, R.J. Bram, and R.J. Noelle, BCMA is essential for the survival of long-lived bone marrow plasma cells. J Exp Med 199 (2004) 91-8.

[39] X.G. Zhang, J.P. Gaillard, N. Robillard, Z.Y. Lu, Z.J. Gu, M. Jourdan, J.M. Boiron, R. Bataille, and B. Klein, Reproducible obtaining of human myeloma cell lines as a model for tumor stem cell study in human multiple myeloma. Blood 83 (1994) 365463.

[40] M.P. Gras, Y. Laabi, G. Linares-Cruz, M.O. Blondel, J.P. Rigaut, J.C. Brouet, G. Leca, R. Haguenauer-Tsapis, and A. Tsapis, BCMAp: an integral membrane protein in the Golgi apparatus of human mature B lymphocytes. Int Immunol 7 (1995) 1093-106.

[41] D.R. Patel, H.J. Wallweber, J. Yin, S.K. Shriver, S.A. Marsters, N.C. Gordon, M.A. Starovasnik, and R.F. Kelley, Engineering an APRIL-specific B cell maturation antigen. J Biol Chem 279 (2004) 16727-35.

[42] K. Mahtouk, F.W. Cremer, T. Reme, M. Jourdan, M. Baudard, J. Moreaux, G. Requirand, G. Fiol, J. De Vos, M. Moos, P. Quittet, H. Goldschmidt, J.F. Rossi, D. Hose, and B. Klein, Heparan sulphate proteoglycans are essential for the myeloma cell growth activity of EGF-family ligands in multiple myeloma. Oncogene 25 (2006) 7180-91.

[43] L. Pellegrini, D.F. Burke, F. von Delft, B. Mulloy, and T.L. Blundell, Crystal structure of fibroblast growth factor receptor ectodomain bound to ligand and heparin. Nature 407 (2000) 1029-34.

[44] J. Schlessinger, A.N. Plotnikov, O.A. Ibrahimi, A.V. Eliseenkova, B.K. Yeh, A. Yayon, R.J. Linhardt, and M. Mohammadi, Crystal structure of a ternary FGF-FGFR-heparin complex reveals a dual role for heparin in FGFR binding and dimerization. Mol Cell 6 (2000) 743-50.

[45] M. Abe, S. Kido, M. Hiasa, A. Nakano, A. Oda, H. Amou, and T. Matsumoto, BAFF and APRIL as osteoclast-derived survival factors for myeloma cells: a rationale for TAClFc treatment in patients with multiple myeloma. Leukemia 20 (2006) 1313-5.

[46] K. Mahtouk, D. Hose, P. Raynaud, M. Hundemer, M. Jourdan, E. Jourdan, V. Pantesco, M. Baudard, J. De Vos, M. Larroque, T. Moehler, J.F. Rossi, T. Reme, H. Goldschmidt, and B. Klein, Heparanase influences expression and shedding of syndecan-1, and its expression by the bone marrow environment is a bad prognostic factor in multiple myeloma. Blood (2007). 
[47] E. Claudio, K. Brown, S. Park, H. Wang, and U. Siebenlist, BAFF-induced NEMOindependent processing of NF-kappa B2 in maturing B cells. Nat Immunol 3 (2002) 958-65.

[48] N. Kayagaki, M. Yan, D. Seshasayee, H. Wang, W. Lee, D.M. French, I.S. Grewal, A.G. Cochran, N.C. Gordon, J. Yin, M.A. Starovasnik, and V.M. Dixit, BAFF/BLyS receptor 3 binds the B cell survival factor BAFF ligand through a discrete surface loop and promotes processing of NF-kappaB2. Immunity 17 (2002) 515-24.

[49] J. Rossi, I. Borghini-Fuhrer, J. Moreaux, G. Requirand, S. Bouseida, M. Picard, A. Ythier, E. Sievers, and B. Klein, A Phase I/II Study of TACl-Ig To Neutralize APRIL[2566] A Phase I/II Study of TACl-Ig To Neutralize APRIL and BLyS in Patients with Refractory or Relapsed Multiple Myeloma or Active Previously-Treated Waldenström's Macroglobulinemia. Blood 106 (2005).

[50] M. Jourdan, J. Moreaux, J.D. Vos, D. Hose, K. Mahtouk, M. Abouladze, N. Robert, M. Baudard, T. Reme, A. Romanelli, H. Goldschmidt, J.F. Rossi, M. Dreano, and B. Klein, Targeting NF-kappaB pathway with an IKK2 inhibitor induces inhibition of multiple myeloma cell growth. Br J Haematol (2007).

[51] C.P. Klerk, S.M. Smorenburg, H.M. Otten, A.W. Lensing, M.H. Prins, F. Piovella, P. Prandoni, M.M. Bos, D.J. Richel, G. van Tienhoven, and H.R. Buller, The effect of low molecular weight heparin on survival in patients with advanced malignancy. $J$ Clin Oncol 23 (2005) 2130-5. 
Moreaux et al.



23 
Moreaux et al.

Figure 2

a

$\mathrm{TACl}^{+} \mathrm{HMCLS}$



TACH HMCLs

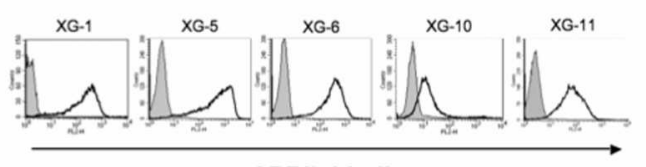

$\mathrm{TACl}^{+} \mathrm{HMCLS}$

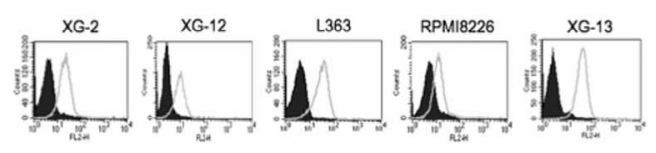

TACH- HMCLS

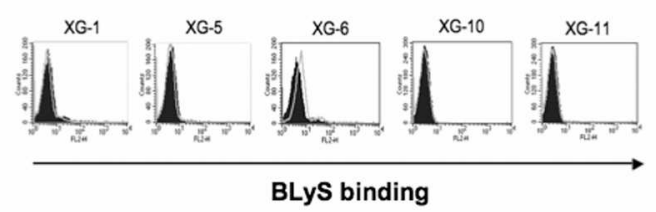

b
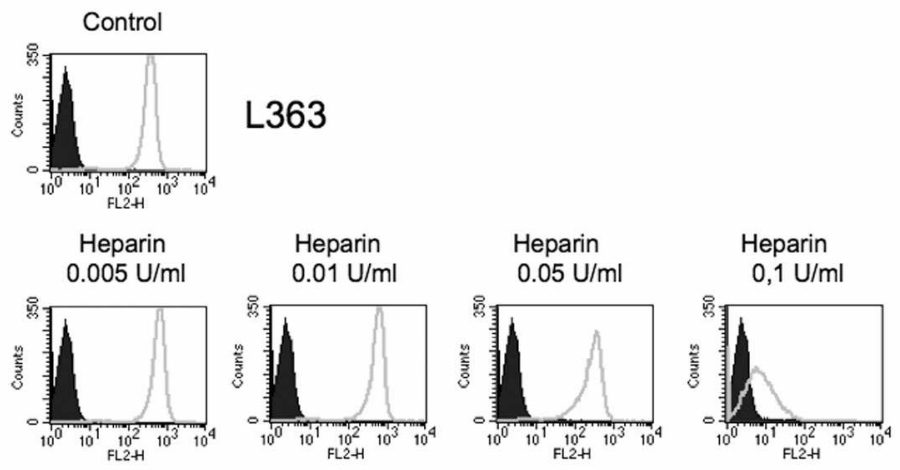

Heparin $0.5 \mathrm{U} / \mathrm{ml}$



Heparin $1 \mathrm{U} / \mathrm{ml}$

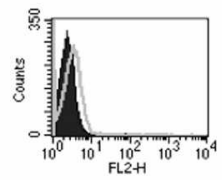

Heparin $4 \mathrm{U} / \mathrm{ml}$



APRIL binding

24 
c
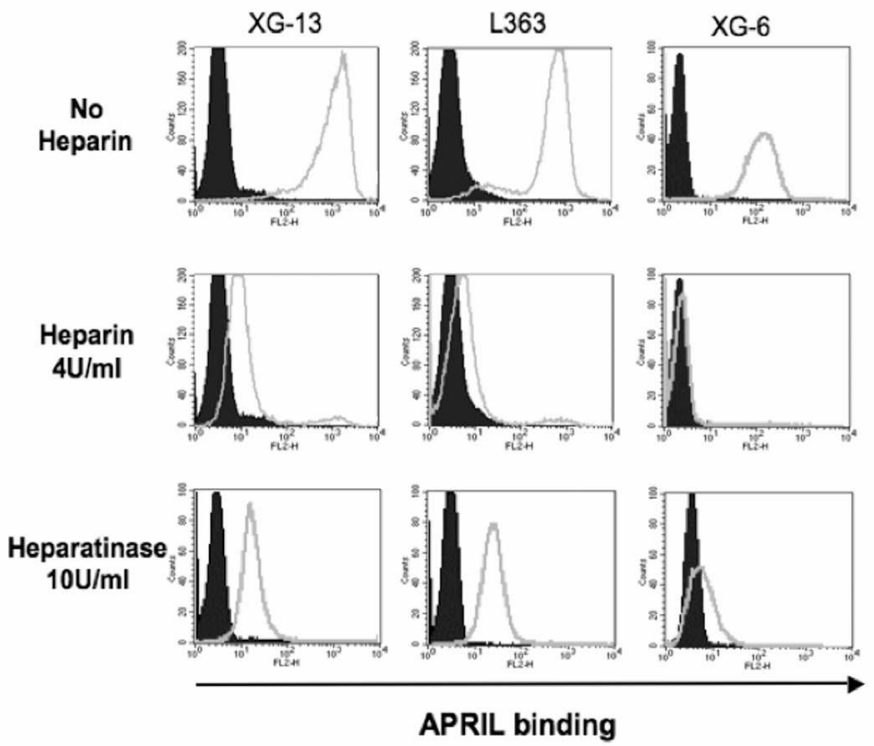

d

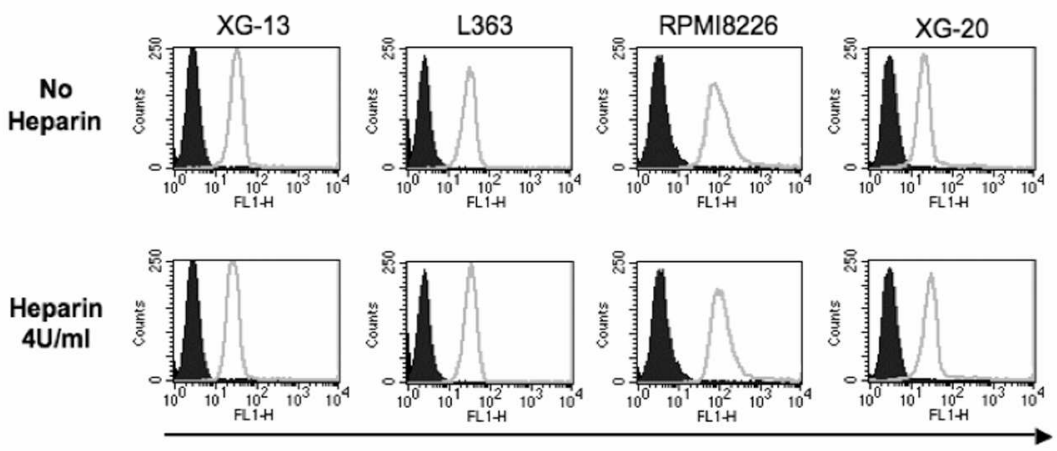

BLyS binding 
Figure 3

a


TACI binding

b

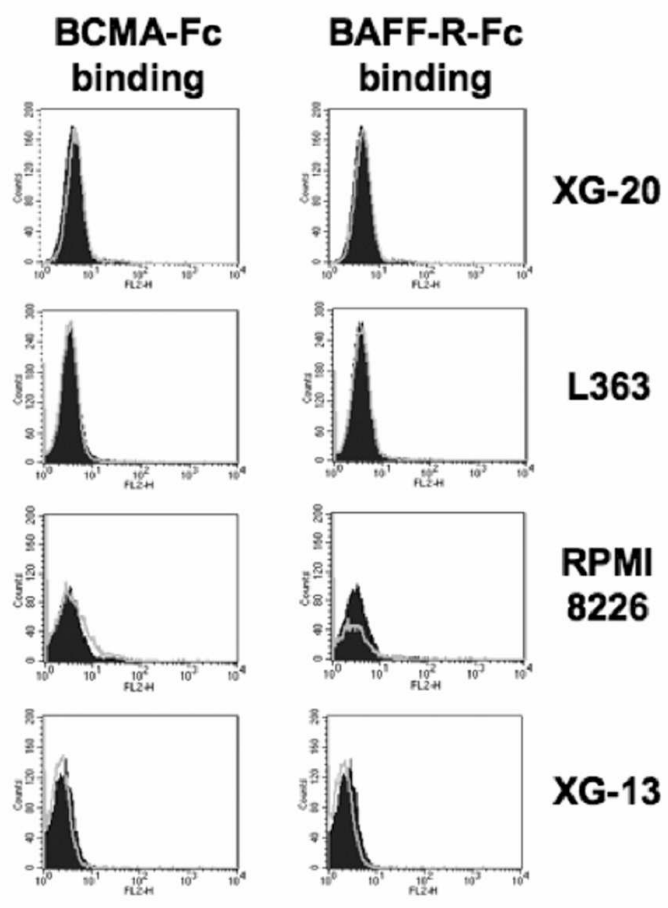


Figure 4

a

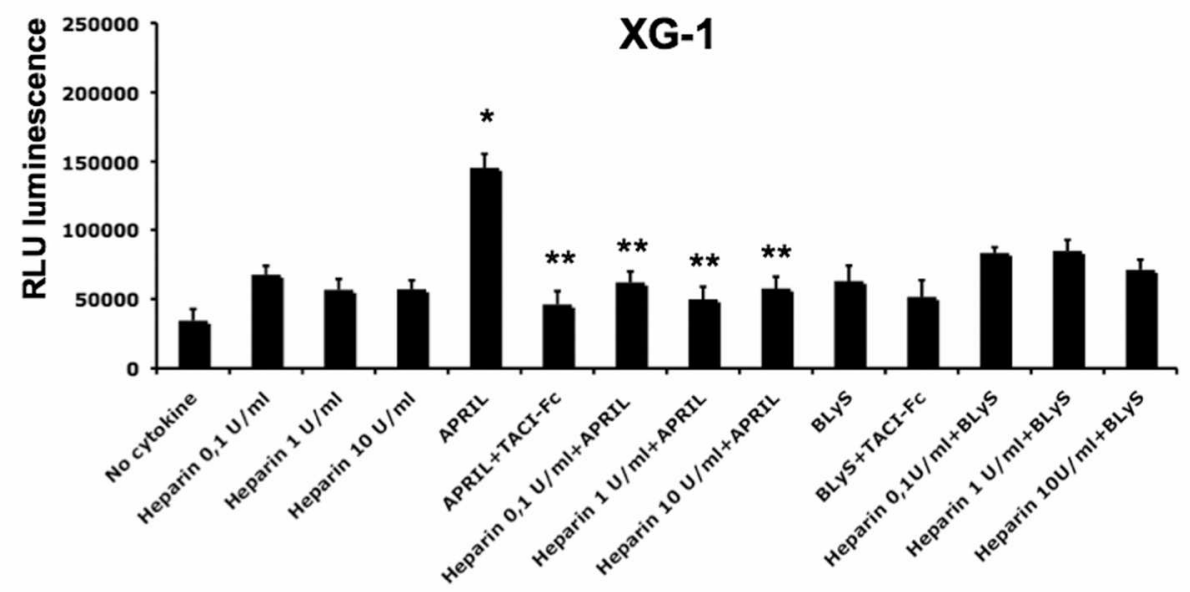

b
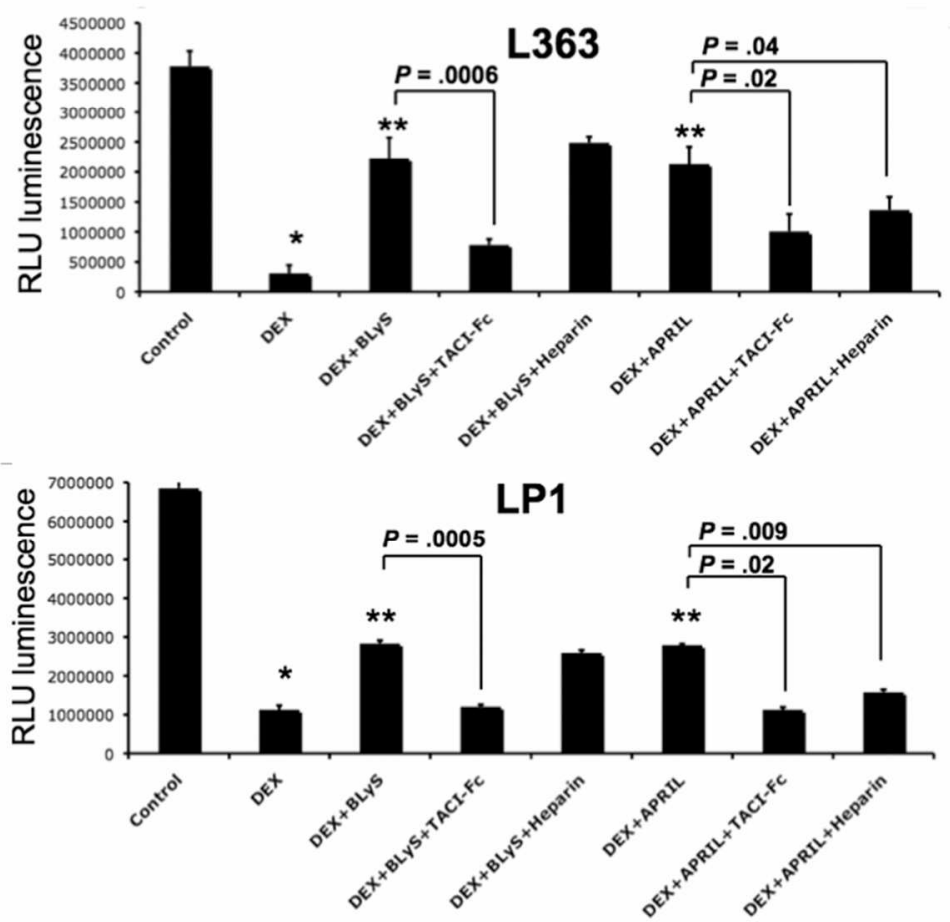
Moreaux et al.

Figure 5 a

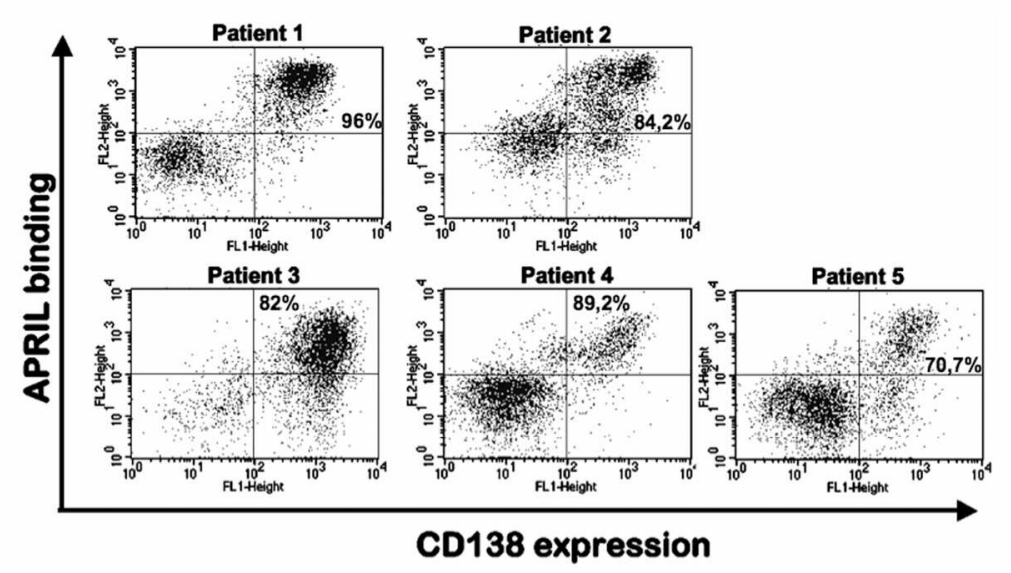

b



C

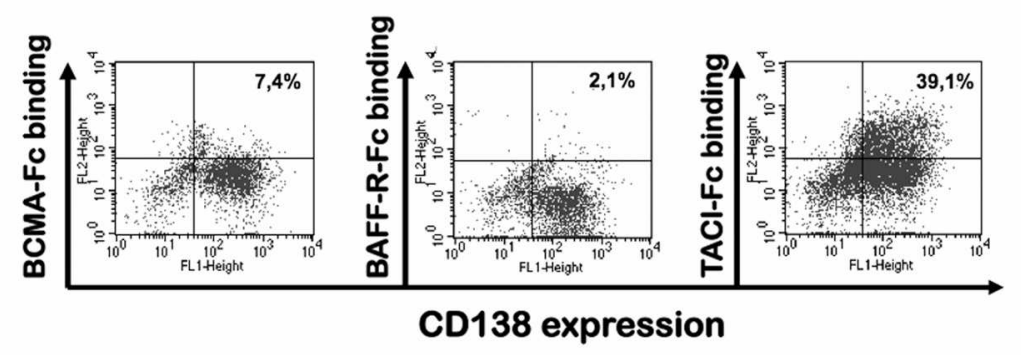

28 